\title{
Insights in the chestnut genetic diversity in Canton Ticino (Southern Switzerland)
}

\author{
By G. L. Beccaro*),1), D. Torello-Marinoni ${ }^{1)}$, G. Binellit ${ }^{2)}$, D. Donno ${ }^{1)}$, \\ P. BocCaCCI ${ }^{1), 4)}$, R. Botta ${ }^{1)}$, A. K. Cerutti ${ }^{1)}$ and M. Conedera ${ }^{3)}$
}

(Received 22 ${ }^{\text {th }}$ June 2012)

\begin{abstract}
Castanea sativa Miller displays a high variability of morphological and ecological traits, vegetative and reproductive habits, nut morphology, wood characteristics, adaptability, and resistance to biotic and abiotic stresses. The present range of distribution of the species has been strongly influenced by human migrations and it is thought that Romans played a crucial role in the spread of the cultivation in Europe, although in some areas there is also evidence of local domestication and spontaneous spread of the tree after the last glacial period. In Switzerland chestnut stands are found mostly in the South (Canton Ticino), a region where the debate about the origin of the local germplasm, whether derived from the survival or spontaneous migration of C. sativa on the territory or due to the introduction of the tree during the Roman colonisation, is still open. This study aims contributing to depict the chestnut genetic situation of the species in Canton Ticino as a contribution to the debate about the native character of the species. The study area is located in Switzerland, on the southern slopes of the Alps, where 3 C. sativa populations were sampled and analysed at 9 SSR loci. Populations showed a high degree of diversity, as it is observed in most natural population of tree species: all nine SSR loci were polymorphic (no fixed alleles were detected), and genetic diversity, measured by expected heterozygosity, was high ranging in the populations between 0.647 and 0.721 , on average. Results suggest that three homogeneous gene pools contributed to the formation of the 3 populations sampled. The genetic germplasm structuring of the analysed chestnut stands is very mild as confirmed by the relatively low level of genetic differentiation and divergence observed among sites.
\end{abstract}

Key words: Castanea sativa, genetic diversity, chestnut population, DNA analysis, SSR.

\section{Introduction}

The Sweet chestnut (Castanea sativa Miller) is the only European of the 7 to 13 species (according to

\footnotetext{
1) Università degli Studi di Torino, Dipartimento di Scienze Agrarie, Forestali e Alimentari, Via Leonardo Da Vinci 44, 10095-Grugliasco (TO), Italy.

$\left.{ }^{2}\right)$ Università dell'Insubria, Dipartimento di Scienze Teoriche e Applicate, Via J. H. Dunant 3, 21100-Varese, Italy.

3) Swiss Federal Research Institute WSL, Via Belsoggiorno 22, CH-6500 Bellinzona, Switzerland.

4) Plant Virology Institute - National Research Council (IVV-CNR), UOS of Grugliasco, Via Leonardo da Vinci 44, 10095-Grugliasco (Torino), Italy.

*) Corresponding author: Gabriele Beccaro. Tel: +39 0116708802 , Fax: +39 0116708658. E-Mail: gabriele.beccaro@unito.it
}

classification, JoHnson, 1988) of the genus Castanea (Fagaceae; $x=12, \quad 2 n=24, \quad J A Y N E S, ~ 1962)$. Many researches attempted to address the history of the European chestnut origin and cultivation (MELLANO et al., 2012; PEREIRA-LORENZO et al., 2012) and recent studies based on cpDNA sequencing analysis (LANG et al., 2007) hypothesize an initial diversification within Asia during the early Eocene followed by intercontinental dispersion and divergence between the Chinese species and the European Castanea sativa during the middle Eocene.

According to the palynological analysis proposed by KREBS et al. (2004) most probable Quaternary refugia of C. sativa consist in six macroregions: the Transcaucasian region; north-western Anatolia; the hinterland of the Tyrrhenian coast from Liguria to Lazio along the Apennine range; the region around Lago di Monticchio (Monte Vulture) in southern Italy; the Cantabrian coast on the Iberian peninsula; and probably also the Greek peninsula (Peloponnese and Thessaly) and north-eastern Italy (Colli Euganei, Monti Berici, EmiliaRomagna). As stated by ConederA et al. (2004a), the first evidences of active chestnut cultivation date back to the third Millennium BC in the Balcanic area (Anatolian Peninsula, northeastern Greece, and southeastern Bulgaria). From these regions, the Greeks first and the Romans later diffused the idea of cultivating chestnut to the West (CONEDERA and KREBS, 2008). The Romans probably introduced the chestnut tree where the species was not present (CONEDERA et al., 2004a).

Starting in the early Middle Ages the cultivation of chestnut for both timber and fruit production became a widespread component of the traditional farming system in most Mediterranean countries and southern parts of Central Europe (CONEDERA and KREBS, 2008). The chestnut tree was used for several purposes (furniture, building construction, poles, and fuel wood), and foliage was first used for livestock bedding and then as a fertilizer (Bounous and ToRello MARINONI, 2005). A major interest in managing chestnut for fruit production as well as in cultivation for self-sufficiency, developed after the Roman period in relation to the socio-economic structures of Medieval Times that gave rise to an autarchic "chestnut civilisation" as in most mountain regions of southern and central Europe (CONEDERA and KREBS, 2008). The role as staple food assumed by the chestnut fruits resulted in an extreme differentiation of the product and of the cultivated varieties (CONEDERA et al., 1994) and a corresponding wide range of germplasm (Grassi, 1992; Bounous et al., 1992; Bounous, 2002; BREISCH, 1995; GoBBIN et al., 2007). The selected varieties can be, nowadays, distinguished by ripening peri- 
od, by the type of use, or by range of distribution and display a correspondent considerable genetic and morphologic polymorphisms (RUDOW and CONEDERA, 2000).

As a result of such a long tradition in chestnut cultivation, the present range of the species has been strongly influenced by humans (MATTIONI et al., 2010) and extends from the Caucasus through Turkey, Greece, and Slovenia to Italy, Switzerland, France, Spain, Portugal, Germany, and Southern England (CONEDERA et al., 2004b). C. sativa is found in small areas bordering North Africa: Morocco, on Beni-Hoçmar Mountains (FERNÁNDEZ De ANA MAGÁn et al., 1997), Algeria, on Atlas range, Tunisia, where it was probably introduced during French domination (BounOus and TORELLO MARINONI, 2005; BERGOUGNOUX et al., 1978). It grows in the Canary and Azores Islands (FERREIRA BATISTA, 1993) and is found to a smaller extent in Syria and Lebanon. At low latitude, chestnut trees are found above $1500 \mathrm{~m}$ a.s.l., as on the slopes of Mount Etna in Italy (PoLACCO, 1938), on the Sierra Nevada in Spain, and in Caucasus where the species thrives at elevation of $1800 \mathrm{~m}$ (FENAROLI, 1945). C. sativa displays a correspondent high variability of morphological and ecological traits, vegetative and reproductive habits, nut morphology, wood characteristics, adaptability, and resistance to biotic and abiotic stresses (LAUTERI et al., 2004; BECCARO et al., 2004; BотTA et al., 2006; CONEDERA et al., 2004b; Mellano et al., 2009).

Unfortunately, up to now studies on the germplasm of the European chestnut only partially contributed to confirm or further detailing the history of the European chestnut origin and cultivation. Many studies indicate the North-East Turkey and the Caucasus region as the most likely centre of origin of present chestnut, confirmed by higher genetic diversity within the Turkish populations and higher level of genetic differentiation among populations (VILLANI et al., 1994; VILLANI et al., 1999). FiNESCHI et al. (2000), however, studying different cpDNA haplotypes could not clarify a possible migration pattern of this species towards Central Europe, whereas MATTiOni et al. (2010) were not able to confirm any genetic relationships between Turkish, Greek and the rest of European chestnut population. Nevertheless the absence of Spanish haplotypes in Turkey combined with their presence in the remaining part of the chestnut tree distribution area enabled these authors to confirm the possible existence of Quaternary chestnut refugia in the Iberian Peninsula as indicated by KREBS et al. (2004). Similarly, in southern Switzerland, the debate about the possible survival or spontaneous migration of $C$. sativa on the territory after the last Glacial Period (HAJDAS et al., 2005) or the introduction of the tree during the Roman colonisation (TINNER et al., 1999; CoNEDERA et al., 2004a) is still open.

Aim of this study is to contribute to depict the chestnut genetic situation of the species in Canton Ticino (southern Switzerland) in order to offer new insights to the debate about the spontaneous or anthropogenic origin of the species. Our basic hypothesis is that a presumed anthropogenic introduction of the tree during the Roman period and the subsequent autarchic character of the chestnut cultivation in the area should have resulted in a genetic pool characterized by less variability with respect to other natural population of Fagaceae such as Quercus spp.

\section{Study Area}

The study area is located on the southern slopes of the Alps in Switzerland, where the climate is warm-temperate and rainy, with a mean annual precipitation of 1700 $\mathrm{mm}$ and a mean annual temperature of about $12{ }^{\circ} \mathrm{C}$. Summer rain (about $800 \mathrm{~mm}$ ) is much more intensive than in Mediterranean areas (SPINEDI and IsOTTA, 2004). Such a climate combined with a predominance of siliceous soils is favorable for the growth of the Sweet Chestnut. According to KREBS et al. (2004), however, the chestnut did not spontaneously recolonize the southern slope of the Swiss Alps. Consistent evidences exist of a rapid increase in the percentage of chestnut pollen starting in the Roman period what claims for an artificial introduction and subsequent cultivation of the chestnut tree in the area (HofsteTter et al., 2006; TINNER et al., 1999). This contrasts with the findings of HAJDAS et al. (2005), who found macro-charcoal of C. sativa in the soils of southern Switzerland dating back to 1500 BC. According to ConEDERA et al. (2004) the introduction or rise in chestnut cultivation coincided with a radical change in local use of land with an active management of chestnut monocultures, probably managed in coppices for pole production both for agricultural and extra-agricultural (military and road constructions, carpentry) purposes.

Many variety names are common in the whole SwissItalian cross-bordering Insubric region (CONEDERA et al. 1994), which indicates a possible flow of genetic materials in Medieval Times.

According to the local medieval bylaws, the chestnut growing areas were strictly differentiated in orchards for fruit productions and coppice stands for timber and pole productions. As a general rule still nowadays orchards are located in the more gentle slope around the settlements whereas coppice stands constituted by wild (unselected and non grafted) growing chestnut trees are confined in the more steep slopes usually in connection with terraced vineyards (CONEDERA and GIUDICI, 1994).

In the last decades of the XIX century, the introduction of alternative food such as maize and potatoes and the progressive abandonment of chestnut as a staple food encouraged the introduction of the high-quality Italian Marroni varieties for commercial purposes. In response to the emergence of chestnut blight (Cryphonectria parasitica) in the area (1948), a breeding program started in 1950 and ended in the selection of 120 hybrid clones (Bazzigher's Euro-Japanese clones) supposed to display a certain resistance to the blight and now conserved in 19 different inventory stands (BAZZIGHER and Miller, 1991). Finally, in the 1980s French Euro-Japanese or European varieties (BREISCH et al., 1995) resistant to the ink disease (Phythophtora spp.) were introduced as potentially valuable germplasm for new plantations. 


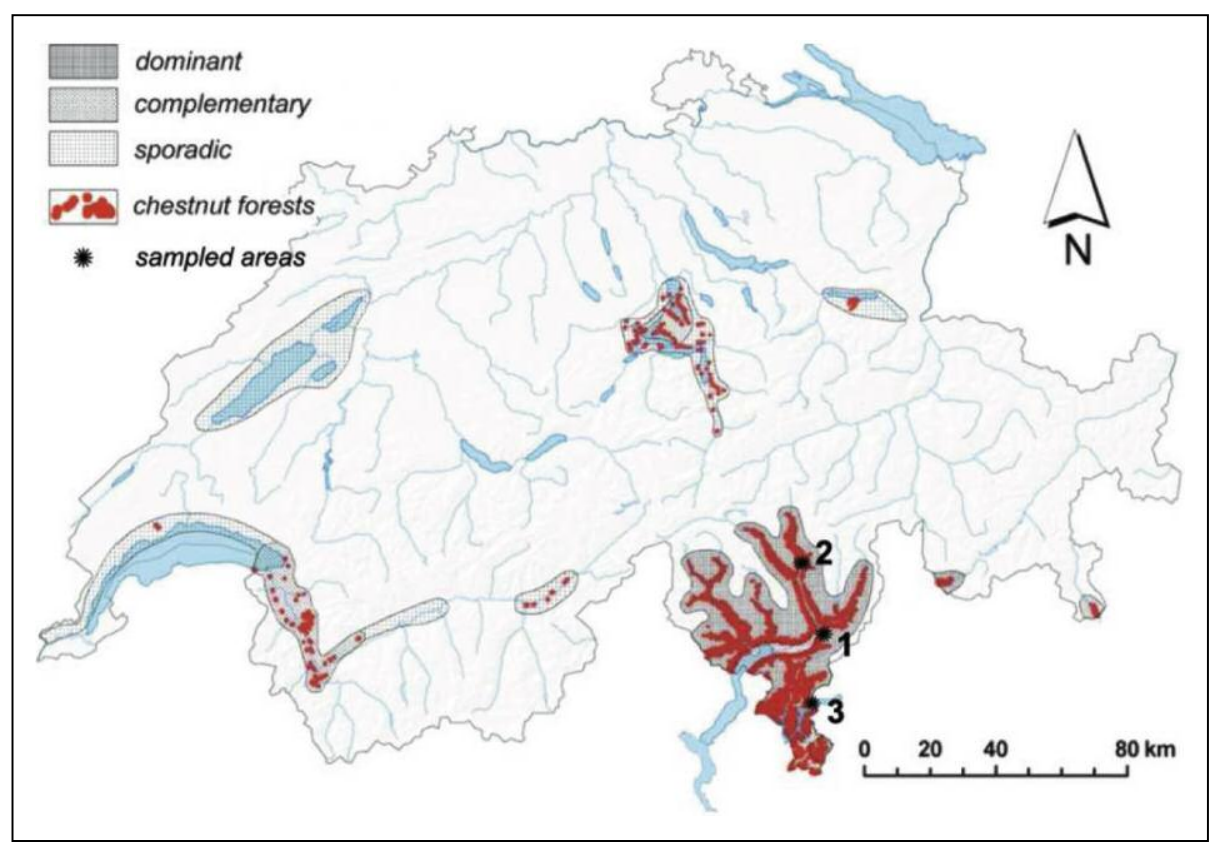

Figure 1. - Actual distribution of chestnut in Switzerland (from CONEDERA and KREBS, 2009) and survey areas: Bellinzona (population 1), Semione (population 2) and Pura (population 3).

Despite the lack of active management of most chestnut groves since the World War II, chestnut forests in the study area still cover 26.000 ha (Fig. 1) of which around 19.000 ha are represented by coppice stands.

\section{Materials and Methods}

\section{Plant material}

A total of 3 coppice stands distributed along a NorthSouth gradient of the Canton Ticino (Switzerland) were chosen for the analysis (Fig. 1). The coppices were selected as far as possible from the existing chestnut orchards.

Young leaves were collected in spring-summer from 30 randomly selected individual stools per stand. A total of 90 individual stools were analyzed. Leaves were reduced to a fine powder in liquid nitrogen using a mortar and pestle and stored at $-80^{\circ} \mathrm{C}$ until used. DNA was extracted from $0.2 \mathrm{~g}$ of young leaf tissue according to THOMAS et al. (1993) with some modifications.

\section{DNA isolation and SSR amplification}

Nine SSR loci were chosen on the basis of their level of polymorphism: CsCAT1, CsCAT8, CsCAT14, CsCAT15, CsCAT16, CsCAT41 (MARINONI et al., 2003) and EMCs38 (BUCK et al., 2003) from C. sativa and QpZAG110 and QpZAG119 (STEINKELLNER et al., 1997) from Quercus petraea. The nine loci are localised on 6 out of the 12 chestnut chromosomes (BARRENECHE et al., 2004). Orthology between Quercus and Castanea for Quercus SSR loci was previously assessed (BARRENECHE et al., 2004; BocCACCI et al., 2004) confirming the suit- ability of QpZAG110 and QpZAG119 for fingerprinting and population genetic studies in chestnut.

PCR was performed in $20 \mu \mathrm{l}$ reaction volumes containing $50 \mathrm{ng}$ of DNA, $0.5 \mathrm{U}$ Taq-DNA polymerase (Ampli Taq Gold, Applied Biosystems, Foster City, CA, USA), $2 \mu \mathrm{l}$ of $10 \mathrm{x}$ PCR buffer (100 mM Tris- $\mathrm{HCl} \mathrm{pH} 8.3,500$ $\mathrm{mM} \mathrm{KCl}$ ), $1 \mu \mathrm{l}$ of $10 \%$ Bovine Albumin Serum (BSA), 1.5 $\mathrm{mM} \mathrm{MgCl}_{2}, 0.2 \mathrm{mM}$ dNTPs, $0.5 \mu \mathrm{M}$ of each primers. Forward primers were labelled with a fluorochrome (6-FAM, HEX, NED or PET).

DNA amplification reactions were performed in a PTC 100 thermal cycler (MJ Research Inc., Watertown, MA, USA) under the following conditions: an initial step of $9 \mathrm{~min}$ at $94^{\circ} \mathrm{C}$, followed by 28 cycles of $30 \mathrm{~s}$ at $94^{\circ} \mathrm{C}, 45 \mathrm{~s}$ at $54^{\circ} \mathrm{C}, 90 \mathrm{~s}$ at $72^{\circ} \mathrm{C}$ and a final extension step of $30 \mathrm{~min}$ at $72^{\circ} \mathrm{C}$. Amplification products were analyzed using a 3130 Genetic Analyzer capillary electrophoresis instrument (Applied Biosystems). Results of the run were processed with GeneMapper software (Applied Biosystems) and alleles were designated by their size in base pairs (bp) using a GeneScan-500 LIZ standard (Applied Biosystems).

\section{Data analysis}

Microsatellite data obtained at nine SSR loci were processed using the software Genepop 4.0 (ROUSSET, 2008) and GENETIX 4.05 (BELKHIR et al., 2004). Allele frequencies, observed $(\mathrm{Ho})$ and expected $(\mathrm{He})$ heterozygosity (NEI, 1978), and linkage disequilibrium (LD) were estimated at each locus. Fisher's exact test using the Markov Chain algorithm (GuO and THOMPSON, 1992) was used to assess deviations from the Hardy-Weinberg 
equilibrium for each population and each locus. WEIR and COCKERHAM's (1984) estimators of $F$-statistics were used to analyse genetic diversity both within and between populations. In particular, $F_{\text {IS }}$ was calculated in order to estimate which proportion of the total genetic variation was due to a departure from the Hardy-Weinberg equilibrium at the population level and $F_{\mathrm{ST}}$ was calculated in order to estimate the proportion of the total genetic variation due to differentiation between populations. The $F_{\mathrm{ST}}$ analogue for microsatellites $R_{\mathrm{ST}}$ (SLATKIN, 1995) was also used, so as to include molecular information relating to the size of differences between the alleles in the differentiation estimates, and it was calculated by the program RSTCALC (GOODMAN, 1997).

To assess the genetic structure of the individual stools, the model-based Bayesian procedure as implemented in the program STRUCTURE 2.1 (PRITCHARD et al., 2000) was used. This model ensures that the incidence of each individual in the original populations may be calculated (BRETON et al., 2008). STRUCTURE was run with the admixture model and 20 trials of $10^{6}$ MCMC replications, following an introduction period (burn-in) of $10^{5}$ repeats for each hypothesis. More recently, it has been suggested that a better estimator of $K$, the number of homogeneous gene pools of origin for the populations studied, is the modal value of $\Delta K$ (EvANNo et al., 2005), the second-order rate of change of the likelihood func- tion with respect to $K$. The estimate of $\mathrm{K}$ was based on $\Delta K$, according to EVANNO et al. (2005). The latter approach was used in the present work to estimate $K$. Twenty runs were carried out for each $K$ value from 1 to 6 (the number of real populations plus 3 ) tested.

\section{Results \\ Genetic diversity}

The analysis of 9 SSR loci at 90 chestnut individual stools displayed a high level of diversity. A total of 67 alleles were detected with a mean of 7.4 alleles per locus. The total number of alleles per locus ranged from 4 (locus CsCAT14) to 15 (locus EMCs38). Number of alleles (averaged over loci) for each population (Table 1) ranged from 5.7 for populations 1 and 2 to 5.9 for population 3. Some alleles were specific for a given population: for population 1: alleles 221, 236, 240 at locus EMCs38 and alleles 93, 106 at locus QpZAG119; for population 2: allele 127 at locus CsCAT15, allele 148 at locus CsCAT16, alleles 232, 242, 260 at locus EMCs38 and allele 87 at locus QpZAG119; for population 3: alleles 209 and 211 at locus CsCAT1, alleles 127 and 133 at locus CsCAT16.

Observed heterozygosity $(H o)$ values varied from 0.433 (locus CsCAT15, population 1) to 0.867 (locus CsCAT1, population 2), with an average of 0.655 ; expect-

Table 1. - Genetic diversity within 3 gene pools at 9 SSR loci: $\mathrm{n}$ : number of samples, $\mathrm{A}_{\mathrm{T}}$ : total number of alleles averaged over samples, A: number of alleles, $\mathrm{H}_{\mathrm{E}}$ : expected heterozygosity, $\mathrm{H}_{\mathrm{O}}$ : observed heterozygosity.

\begin{tabular}{|c|c|c|c|c|c|c|c|c|c|c|}
\hline \multirow[t]{3}{*}{ LOCUS } & & \multicolumn{3}{|c|}{ Gene pools } & \multirow{2}{*}{\multicolumn{3}{|c|}{$\begin{array}{l}\text { POP2, } \\
\text { Semione, }(n=30)\end{array}$}} & \multirow{2}{*}{\multicolumn{3}{|c|}{$\begin{array}{l}\text { POP3, } \\
\text { Pura }(n=30)\end{array}$}} \\
\hline & & & I, & =30) & & & & & & \\
\hline & $\mathbf{A}_{\mathrm{T}}$ & $\mathbf{A}$ & $\mathbf{H}_{\mathrm{E}}$ & $\mathbf{H}_{\mathbf{O}}$ & $\mathbf{A}$ & $\mathbf{H}_{\mathrm{E}}$ & $\mathbf{H}_{\mathbf{O}}$ & $\mathbf{A}$ & $\mathbf{H}_{\mathrm{E}}$ & $\mathbf{H}_{\mathbf{O}}$ \\
\hline CsCAT1 & 9 & 5 & 0.624 & 0.633 & 5 & 0.615 & 0.867 & 8 & 0.750 & 0.833 \\
\hline CsCAT8 & 5 & 5 & 0.743 & 0.800 & 5 & 0.726 & 0.700 & 5 & 0.681 & 0.700 \\
\hline CsCAT14 & 4 & 4 & 0.693 & 0.767 & 4 & 0.674 & 0.667 & 4 & 0.688 & 0.533 \\
\hline CsCAT15 & 6 & 5 & 0.428 & 0.433 & 5 & 0.580 & 0.633 & 5 & 0.620 & 0.667 \\
\hline CsCAT16 & 6 & 3 & 0.533 & 0.586 & 4 & 0.403 & 0.500 & 5 & 0.566 & 0.643 \\
\hline CsCAT41 & 8 & 6 & 0.637 & 0.600 & 5 & 0.639 & 0.862 & 8 & 0.796 & 0.828 \\
\hline EMCs38 & 15 & 11 & 0.770 & 0.520 & 12 & 0.867 & 0.565 & 7 & 0.816 & 0.526 \\
\hline QpZAG110 & 5 & 5 & 0.599 & 0.483 & 4 & 0.674 & 0.483 & 5 & 0.743 & 0.643 \\
\hline QpZAG119 & 9 & 7 & 0.796 & 0.679 & 7 & 0.758 & 0.750 & 6 & 0.831 & 0.793 \\
\hline Mean & 7.4 & 5.7 & 0.647 & 0.611 & 5.7 & 0.659 & 0.670 & 5.9 & 0.721 & 0.685 \\
\hline
\end{tabular}

Table 2. - Test of Hardy-Weinberg equilibrium. $F_{\text {IS }}$ values are reported for each locus and each population. Values in bold are significantly different from zero with $p<0.01$.

\begin{tabular}{|l|l|l|l|l|l|l|l|l|l|}
\hline & CsCAT1 & CsCAT8 & CsCAT14 & CsCAT15 & CsCAT16 & CsCAT41 & EMCs38 & QpZAG110 & QpZAG119 \\
\hline POP1 Bellinzona & -0.015 & -0.078 & -0.108 & -0.013 & -0.102 & 0.059 & $\mathbf{0 . 3 2 9}$ & 0.197 & 0.150 \\
\hline POP2 Semione & $\mathbf{- 0 . 4 2 0}$ & 0.036 & 0.011 & -0.094 & -0.246 & -0.358 & $\mathbf{0 . 3 5 3}$ & 0.288 & 0.011 \\
\hline POP3 Pura & -0.114 & -0.028 & 0.228 & -0.077 & -0.138 & -0.040 & $\mathbf{0 . 3 6 2}$ & 0.138 & 0.046 \\
\hline
\end{tabular}


Table 3. $-\mathrm{F}_{\mathrm{ST}}$, $\mathrm{R}_{\mathrm{ST}}$ and Genetic distances values for each population pair.

\begin{tabular}{|l|l|l|l|}
\hline & $\mathrm{F}_{\mathrm{ST}}$ & $\mathrm{R}_{\mathrm{ST}}$ & Genetic distances \\
\hline POP1 Bellinzona- POP2 Semione & 0.0409 & 0.0245 & 0.085 \\
\hline POP1 Bellinzona- POP3 Pura & 0.0287 & 0.0454 & 0.062 \\
\hline POP2 Semione- POP3 Pura & 0.0192 & 0.0143 & 0.041 \\
\hline
\end{tabular}

ed heterozygosity $(\mathrm{He})$ ranged from 0.403 (locus CsCAT16, population 2) to 0.867 (locus EMCs38, population 2), with an average of 0.676 (Table 1). These values are higher for the population 3 (average $\mathrm{He}: 0.721$ ) of the Pura region than for the two other populations (1 and 2) of Bellinzona and Semione (average $\mathrm{He}$ : 0.647 and 0.659 , respectively).

The deviation of $F_{\text {IS }}$ from zero was tested for all loci in all populations under the null hypothesis of HardyWeinberg equilibrium (HWE, significance level $\alpha=0.01$ ). One locus, EMCs38, was found at disequilibrium in all three populations; the only other significant test was relative to locus CsCAT1 in Semione population (Table

Table 4. - Analysis of population structure according to a Bayesian clustering method. The populations studied derive their genetic structure from three inferred populations ('gene pools') of origin. The proportion of membership of each inferred population in the populations studied is indicated. The main contribution is in bold.

\begin{tabular}{|l|l|l|l|}
\hline & I & II & III \\
\hline POP1 Bellinzona & $\mathbf{0 . 4 9 5}$ & 0.227 & 0.278 \\
\hline POP2 Semione & 0.200 & $\mathbf{0 . 5 4 9}$ & 0.251 \\
\hline POP3 Pura & 0.231 & 0.274 & $\mathbf{0 . 4 9 5}$ \\
\hline
\end{tabular}

2). The presence of one locus in HW disequilibrium for all three populations can be due to several different factors (presence of null alleles, population stratification, genotyping errors or some other artefact); however, estimates of genetic differentiation and of population structure were not affected by dropping this locus from the dataset.

Linkage disequilibrium (LD), the non-random association of the alleles at different loci, was also investigated. When independent loci were tested, we found significant LD values for the pairs of loci: CsCAT8-CsCAT14 (population 3), CsCAT8-CsCAT15 (population 1), CsCAT8-QpZAG110 (population 3), CsCAT16-CsCAT14 (population 1), CsCAT1-CsCAT14 (population 2), CsCAT1-QpZAG119 (population 1), CsCAT14QpZAG119 (population 1) and EMCs38-QpZAG119 (population 1). As for the loci linked on the genetic map built by BARRENECHE et al. (2004), we found significant LD values for the pairs CsCAT15-CsCAT41, CsCAT1CsCAT15 and CsCAT1-CsCAT41 in all populations with the exception of pair CsCAT1-CsCAT15 in population 2, whilst we did not detect LD for the pair CsCAT8CsCAT16.

\section{Genetic differentiation}

The overall genetic differentiation among populations was significant, albeit low: about $3 \%\left(F_{\mathrm{ST}}=0.029\right.$, confi-

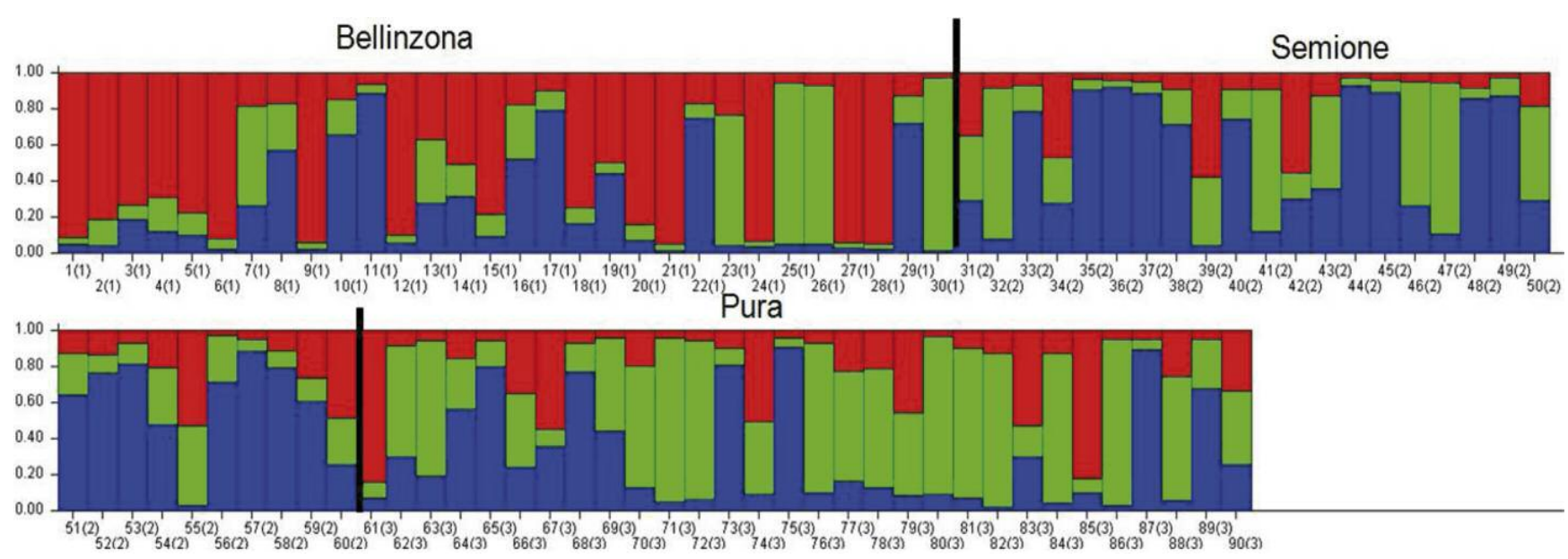

Figure 2. - Analysis of population structure according to a Bayesian clustering method. The populations derive their genetic pool from three populations of inferred origin. The figure shows quantitative analysis of the genetic structure for the three entities addressed in this work. Each bar represents a single individual analyzed. 
dence interval at $95 \%$ is $0.018<F_{\mathrm{ST}}<0.043$ ) of the total genetic variation can be attributed to differentiation among populations. The same procedures for $R_{\mathrm{ST}}$ yielded an estimated overall $R_{\mathrm{ST}}=0.028$, with a confidence interval at $95 \%$ of $0.018<R_{\mathrm{ST}}<0.080$. Then, we tested the significance for the three pairwise comparisons. All $F_{\mathrm{ST}}$ pairwise comparisons were significant: from highest to lowest, 0.019 (population 2 vs. population 3), 0.029 (1 vs. 3 ) and 0.041 ( 1 vs. 2 ); the same comparisons for $R_{\mathrm{ST}}$ yielded the highest value, 0.045 , for population 1 vs. population 3 , followed by 0.025 ( 1 vs. 2 ) and 0.014 ( 2 vs. 3) (Table 3). It can be easily seen that $F_{\mathrm{ST}}$ and $R_{\mathrm{ST}}$ showed different results. We also estimated the genetic distance among populations by means of Nei's genetic distance; the relative distances were: 0.085 (1 vs. 2), 0.062 (1 vs. 3) and 0.041 (2 vs. 3) (Table 3).

Furthermore, a preliminary analysis was carried out to investigate the population structure in the three gene pools. In order to research population structure and assign individuals to sub-populations based on the genotypes, a model-based Bayesian procedure, as implemented in the software STRUCTURE (PRITCHARD et al., 2000) was applied. This approach estimates the most likely number of clusters $(K)$, or homogeneous gene pools, which have originated the present populations. The model-based Bayesian procedure highlighted a sharp signal at $K=3$, thus indicating that three gene pools shaped the genetic structure of the populations analyzed. To check the composition of each population and each individual with respect to each population, further analysis was therefore carried out based on $K=3$. The final proportion of each of the three hypothetical gene pools present in each individual was obtained and the results are shown in Table 4 and in Figure 2. The proportion of membership of each inferred population in the populations studied was nearly $50 \%$ (Table 4). This result highlights that each gene pool presents a high degree of admixture, according with the low differentiation level found between populations, since value greater than 0.75 are necessary for indicating membership of one population to one gene pool. On average half of chestnut individuals for each population showed a strong component derived from one distinct gene pool.

\section{Discussion}

In this study, $C$. sativa populations show a high degree of diversity, as is observed in most natural population of tree species (HAMRICK et al., 1992): all nine analysed loci are polymorphic (no fixed alleles were detected), and genetic diversity, measured by heterozygosity, appears to be high. The average $\mathrm{He}$ values obtained for the three populations studied are in the range $0.65-0.72$ in full agreement with those observed in natural populations of other Fagaceae: MUIR and SCHLÖTTERER (2005) registered in a set of European populations of $Q$. petraea e $Q$. robur $\mathrm{He}$ values between 0.3 and 0.96 . The smaller range of variation in our populations is easily explained by the more restricted geographic range analysed. The same effect is evident when comparing our results to those obtained by STREIFF et al. (1998) for the same species. Last, in a recent work on Italian populations of
$Q$. cerris, heterozygosity levels between 0.65 and 0.85 were found (BERTOLASI et al., pers. comm.; BINELLI et al., in prep.). It appears that the managing practices adopted in the period of greatest importance for chestnut cultivation have been respectful, although involuntarily, of the starting levels of genetic variation of the species. Deviations from Hardy-Weinberg equilibrium were found for locus EMCs38 in all three populations tested. The most probable cause is the provenance of the marker. In fact, marker EMCs38 comes from a different set of microsatellites of Castanea what probably resulted in missing the presence of null alleles, as indicated also by the estimates of all positive $F_{\text {IS }}$ values at this locus. Other two loci are characterised by positive $F_{\text {IS }}$ values, but do not deviate from HWE, QpZAG110 and QpZAG119. These markers were developed in the phylogenetically more distant Quercus petraea and hence have possibly been unwillingly selected for higher ability to detect differentiation, due to the presence of different homozygotes in the populations studied. This is confirmed by the data on differentiation discussed later. The levels of LD in our populations are not high: once the significant $L D$ values have been removed which can be ascribed to physical linkage between loci (SSRs CsCAT1, CsCAT15 and CsCAT41, BARRENECHE et al., 2004), eight pairs of loci remain, none of which has significant LD across all three populations studied. Besides, because the significance level was set at $\alpha=0.05$, a frequency of one false positive out of 20 is expected and 36 pairs were tested for each population (considering also the linked markers), a conservative analysis implies that only those populations carrying at least two disequilibria are carrying "true" LD. In our hands, the population characterised by the highest levels of LD (five out of the eight significant comparisons) is Bellinzona. This result could be the footprint of a recent event of mixing among populations, as indicated also by the analysis of the genetic structure discussed later. Presence of $\mathrm{LD}$ can also be diagnostic of a role as potential refugium for that particular population. In our case, the term refugium must be taken with the meaning of a key population maintained throughout the recent history of the species. Finally, another cause for LD is genetic drift, but the number of SSRs used prevented us from testing for bottlenecks, since the most common tests rely on at least 20 loci to yield sound results (PIRY et al., 1989). We can conclude that the low level of $\mathrm{LD}$ found indicates that the three populations under study do not show evidence of loss of variability due to management practices and/or the evidence of past events of reduction in size.

A significant level of genetic differentiation was found among the Canton Ticino populations of $C$. sativa. The estimate, based on $F_{\mathrm{ST}}=0.029$, is in the lower part of the range already observed for other Fagaceae; MUIR and SCHLÖTTERER (2005) observed between Quercus petraea and Quercus robur $F_{\mathrm{ST}}$ values between 0.001 and 0.232 , average 0.05 , based on 20 microsatellites in 12 populations. In the already mentioned work on $Q$. cerris (BERTOLASI et al., pers. comm.; BINELLI et al., in prep.), $F_{\mathrm{ST}}=0.059$ was estimated for 23 Italian populations studied by eight SSRs. In another large scale 
study, five Italian populations of $Q$. petraea analysed at five SSRs were characterised by $G_{\mathrm{ST}}=0.18$ (BRUSCHI et al., 2003). A closer look at the single locus level indicates that the two markers exhibiting the highest differentiation are QpZAG110 and QpZAG119, developed for Quercus petraea. The genetic divergence between populations was also estimated by RST, the $F_{\mathrm{ST}}$ analogue based on the stepwise mutation model. An overall value of $R_{\mathrm{ST}}=0.028$ was found, indicating that the differentiation rate has not changed in the populations studied, due to the ability of $R_{\mathrm{ST}}$ to detect differentiation events older than those revealed by $F_{\mathrm{ST}}$ (SLATKIN, 1995; MAMELI et al., 2008). This also implies that the amount of gene flow remained constant; hence the history chestnut populations in Canton Ticino has not changed over the last centuries.

When dealing with conservation and phylogeographic issues, it is often necessary to detect $K$, the number of panmictic units or 'gene pools' in the data, in order to be able to suggest possible mechanisms that have shaped the genetic variability observed. The use of a Bayesian approach to the detection of $K$ has become increasingly popular in the last decade (BERTORELLE and EXCOFFIER, 1998; PRITCHARD et al., 2000). In the present study it was possible to estimate $K=3$ as the number of inferred populations from which the studied populations derive. The most precise interpretation of this value is that three homogeneous gene pools contributed to the three populations sampled. This implies that the genetic structuring is very mild in the Canton Ticino chestnut population, as already observed by the relatively low levels of differentiation. Unfortunately for the purposes of our study this does not make possible to indicate with an acceptable degree of certainty the origin of the populations studied yet. However, this study paves the way for the assessment on a larger scale of the genetic characteristics of this important species. Also the use of uniparentally inherited markers will allow us to shed more light on this issue.

\section{References}

Barreneche, T., M. Casasoli, K. Russell, A. AkKaK, H. Meddour, C. Plomion, F. Villani and A. Kremer (2004): Comparative mapping between Quercus and Castanea using simple-sequence repeats (SSR). Theoretical and Applied Genetics 108:558-566. doi: 10.1007/s00122-003-1462-2.

Beccaro, G. L., R. Botta, D. Torello Marinoni, A. AKKaK and G. Bounous (2004): Application and evaluation of morphological, phoenological and molecular techniques for the characterization of Castanea sativa Mill. cultivars. Acta Horticulturae 693: 453-457.

Belkhir, K., P. Borsa, L. ChiKhi, N. Raufaste and F. BonHOMME (2004): GENETIX version 4.05. Universuty of Montpellier II, Montpellier (France). http://www. genetix.univ-montp2.fr/genetix/intro.htm.

Bergougnoux, F., A. Verlhac, H. Breisch and J. Chapa (1978): Le châtaignier. INVUFLEC, Paris, 192 p.

Boccacci, P., A. AKKaK, D. TOREllo Marinoni, G. Bounous and R. BoTTA (2004): Typing European chestnut (Castanea sativa Mill.) cultivars using oak simple sequence repeat markers. HortScience $\mathbf{3 9}(6)$ : 1212-1216.

Bounous, G., M. Bouchet and L. Gourdon (1992): Reconstruction of traditional chestnut orchard. Experiences in Piedmont and Southern France. L'Informatore Agrario, 9: 155-160.

Bounous, G. (2002): Il Castagno: coltura, ambiente ed utilizzazioni in Italia e nel mondo. Edagricole - Edizioni Agricole del Il Sole 24 ORE Edagricole, Bologna. p. XIV +312 .

Bounous, G. and D. Torello MARINONI (2005): Chestnut: botany, horticulture, and utilization. Horticultural reviews. Edit. J. Janick; Wiley \& Sons Inc., New Jersey: vol. 31: 291-347.

Botta, R., P. Guaraldo, M. G. Mellano and G. Bounous (2006): DNA typing and quality evaluation of chestnut (Castanea sativa Mill.) cultivars. International Symposium "Optimization, Productivity and Sustainability of Chestnut Ecosystems in Mediterranean Europe" Catania (Italy), 23-26 February 2005. Advances in horticultural science 1: 96-100.

BAzzigher, G. and G. A. Miller (1991): Blight-resistant chestnut selections of Switzerland: a valuable germ plasm resource. Plant Disease 75, 5-9.

Bertorelle, G. and L. ExCOFFIER (1998): Inferring admixture proportions from molecular data. Mol. Biol. Evol., 15: 1998-1311.

Buck, E., M. Hadonou, C. James, D. Blakesley and K. Russell (2003): Isolation and characterisation of polymorphic microsatellites in European chestnut (Castanea sativa Mill.). Molecular Ecology Notes 3: 239-241.

Breisch, H. (1995): Châtaignes et marrons. Ctifl, Paris. p. 239.

Breton, C., C. Pinatel, F. Médail, F. Bonhomme and A. Bervillé (2008): Comparison between classical and Bayesian methods to investigate the history of olive cultivars using SSR-polymorphisms. Plant Science 175: 524-532.

Bruschi, P., G. G. Venderamin, F. Bussotti and P. Grossoni (2003): Morphological and molecular diversity among Italian populations of Quercus Petraea. Annals of Botany 91: 707-716.

Conedera, M. (1993): Cancro corticale del castagno. Principali caratteristiche epidemiologiche e misure di controllo. Ber. Eidg. Forsch.anst. Wald Schnee Landsch. $335,40 \mathrm{pp}$.

Conedera, M., P. Krebs, W. Tinner, M. Pradella and D. TORRIANI (2004a): The cultivation of Castanea sativa (Mill.) in Europe, from its origin to its diffusion on a continental scale. Vegetation History and Archaeobotany 13: 161-179.

Conedera, M., M. C. Manetti, F. Giudici and E. Amorini (2004b): Distribution and economic potential of the Sweet chestnut (Castanea sativa Mill.) in Europe. Ecologia Mediterranea 30, 2: 179-193.

Conedera, M. and P. Krebs (2008): Switzerland. In: Avanzato, D. (ed) Following Chestnut Footprints (Castanea spp.). Cultivation and Culture, Folklore and History, Traditions and Uses. Scr. Hortic. 19: 149-154.

Evanno, G., S. REgnaut and J. Goudet (2005): Detecting the number of clusters of individuals using the software STRUCTURE: a simulation study. Molecular Ecology 14: 2611-2620. 
FEnARoli, L. (1945): Il castagno. Reda, Roma, Italy. p. 222.

Fernández De Ana Magán, F. J., M. C. Verde Figueiras and A. Rodriguez Fernandez (1997): O souto, un ecosistema en perigo. Xunta de Galicia. p. 205.

Ferreira BAtista, J. G. (1993): The use of chestnut logs as a substrate for the cultivation of shiitake (Nentinus edodes). Proc. Intl. Cong. Chestnut, Spoleto (PG), Italy. p. 417-420.

Fineschi, S., D. Taurchini, G. MÜller-Starck and M. CONEDERA (2000): Genetic characterization of cultivated varieties of European Chestnut (Castanea sativa Mill.) in Southern Switzerland. (III) Analysis of RAPD's molecular markers. - In: Comunità Montana Monti Martani e Serano of Spoleto; Istituto di Coltivazioni Arboree University of Perugia (eds) Proceedings of the International Congress on Chestnut Spoleto, Italy, October 20-23, 1993. p. 309-313.

Gobbin, D., L. Hohl, L. Conza, M. Jermini, C. Gessler and M. CONEDERA (2007): Microsatellite-based characterization of the Castanea sativa cultivar heritage of southern Switzerland. Genome, 50(12): 1089-1103.

GoodmAn, S. J. (1997): RST CALC: a collection of computer programs for calculating unbiased estimates of genetic differentiation and determining their significance for microsatellite data. Molecular Ecology 6 : 881-885. http://helios.bto.ed.ac.uk/evolgen/.

GRASSI, G. (1992): Individuazione, valutazione e conservazione di biotipi e cultivar di castagno da frutto. Atti Convegno "Germoplasma Frutticolo," Alghero (SS), Italy. p. 603-606.

Guo, S.W. and E. A. Thompson (1992): Performing the exact text of Hardy-Weinberg proportions for multiple alleles. Biometrics 48: 361-372.

Hajdas, I., N. SchlumpF, N. Minikus-Stary, F. HAGEdorn, E. Eckmeier, W. Schoch, C. Burga, G. Bonani, M. W. I. SCHMIDT and P. CheRUBINI (2005): Radiocarbon ages of soil charcoals from the southern Alps, Ticino Switzerland. In: $10^{\text {th }}$ International Conference on Accelerator Mass Spectrometry, Berkeley, CA, pp. 398-402.

Hamrick, J. L., M. J. W. GodT and S. L. Sherman-Broyles (1992): Factors influencing levels of genetic diversity in woody plant species. New Forests, 6: 95-124.

Hofstetter, S., W. Tinner, S. VAlsecchi, G. Carraro and M. ConederA (2006): Lateglacial and Holocene vegetation history in the Insubrian Southern Alps - New indications from a small-scale site. Veg. Hist. Archaeobot. 15: 87-98.

JAYNES, R. A. (1962): Chestnut chromosomes. Forest Science 8: 372-377.

Johnson, G. P. (1988): Revision of Balanocastanon (Fagaceae). Journal of the Arnold Arboretum 69(1): 25-49

Krebs, P., M. Conedera, M. Pradella, D. Torrioni, M. FELBER and W. TINNER (2004): Quaternary refugia of the sweet chestnut (Castanea sativa Mill.): an extended palynological approach. Vegetation History and Archaeobotany 13: 145-160.

Lang, P., F. Dane, T. L. Kubisiak and H. Huang (2007): Molecular evidence for an Asian origin and unique westward migration of species in the genus Castanea via Europe to North America. Molecular Phylogenetics and Evolution 43: 49-59.

Lauteri, M., A. Pliura, M. C. Monteverdi, E. Brugnoli and F. Villani (2004): Genetic variation in carbon isotope discrimination in six European populations of Castanea sativa Mill. originating from contrasting localities. Journal of Evolutionary Biology 17: 1286-1296.

Mameli, G., R. Filigheddu, G. Binelli and M. Meloni (2008): The genetic structure of the remnant populations of Centaurea horrida in Sardinia and associated islands. Annals of Botany, 101: 633-640.

Marinoni, D., A. AkKaK, G. Bounous, K. J. Edwards and R. BоттA (2003): Development and characterization of microsatellite markers in Castanea sativa (Mill). Molecular Breeding 11: 127-136.

Mattioni, C., M. Cherubini, D. Taurchini, F. Villani and M. A. Martin (2010): Genetic diversity in european chestnut populations. Acta Horticulturae (ISHS) 866: 163-167.

Mellano, M. G., G. L. Beccaro, G. Bounous, C. Trasino and A. BARREL (2009): Morpho-biological and sensorial quality evaluation of chestnut cultivars in Aosta Valley (Italy) Acta Horticulturae 815: 125-132.

Mellano, M. G., G. L. Beccaro, D. Donno, D. Torello Marinoni, P. Boccacci, S. CANTERINo, A. K. Cerutti and G. Bounous (2012): Castanea spp. biodiversity conservation: collection and characterization of the genetic diversity of an endangered species. Genetic Resources And Crop Evolution, First Online, doi: 10.1007/s10722012-9794-x.

NEI, M. (1978): Estimation of average heterozygosity and genetic distance from a small number of individuals. Genetics 89: 583-590.

Pereira-Lorenzo, S., A. Ballester, E. Corredoira, A. M. Vieitez, S. Agnanostakis, R. Costa, G. Bounous, R. BotTa, G. L. Beccaro, T. L. KubisiaK, M. Conedera, P. Krebs, T. Yamamoto, Y. SAwamura, N. Takada, J. Gomes-Laranjo, A. M. Ramos-Cabrer (2012): Chestnut Breeding. In: M. L. BADENES and D. BYRNE, Fruit breeding/Springer Series „Handbook of Plant Breeding“, Springer, Heidelberg, pp. 729-770.

PIRY, S., G. LuIKART and J-M. CoRnuet (1999): BOTTLENECK, a computer program for detecting recent reductions in the effective population size using allele frequency data. The Journal of Heredity 90: 502-503.

PolACCO, F. (1938): Indagine sulla coltivazione del castagno da frutto in Italia. Bollettino mensile di statistica agraria e forestale, Roma, Istat.

Pritchard, J. K., M. Stephens and O. Donnelly (2000): Inference of population structure using multi locus genotype data. Genetics 155: 945-959.

RoussET, F. (2008): GENEPOP'007: a complete re-implementation of the GENEPOP software for Windows and Linux. Molecular Ecology Resourches 8: 103-106.

Rudow, A. and M. Conedera (2000): Floral characters and recognition of cultivars of sweet chestnut (Castanea sativa Mill.) in Southern Switzerland. Botanica Helvetica 111(1): 1-23.

Santamour, F. S. JR., A. J. McArdle and R. A. JaYnes (1986): Cambial isoperoxidase patterns in Castanea. Journal of Environmental Horticulture 4(1): 14-16.

SLATKIN, M. (1995): A measure of population subdivision based on microsatellite allele frequencies. Genetics 139: 457-462.

Slatkin, M. and N. BARTON (1989): A comparison of three indirect methods for estimating average level of gene flow. Evolution 43: 1349-1368. 
SpINEDI, F. (1991): Il clima del Ticino e della Mesolcina con accenni di climatologia generale. Rapporto di lavoro no 167 dell'Istituto svizzero di meteorologia, Zurigo.

Steinkellner, H., S. Fluch, E. TuretscheK, C. Lexer, R. Streiff, A. Kremer, K. Burg and J. Glassl (1997): Identification and characterization of (GA/CT)n microsatellite loci from Quercus petraea. Plant Molecular Biology 33: 1093-1096.

StreifF, R., T. LABbe, R. BACILIERI, H. SteinkellneR, J. Glossl and A. KREMER (1998): Within-population genetic structure in Quercus robur L. and Quercus petraea (Matt.) Liebl. assessed with isozymes and microsatellites. Mol Ecol 7: 317-328.

Tinner, W., P. Hubschmid, M. Wehrli, B. Ammann and M. CONEDERA (1999): Long-term forest fire ecology and dynamics in southern Switzerland. Journal of Ecology 87: 273-289.
Thomas, M. R., S. Matsumoto, P. Cain and N. S. Scott (1993): Repetitive DNA of grapevine: classes present and sequences suitable for cultivar identification. Theoretical and Applied Genetics 86: 985-990.

Villani, F., M. Pigliucci and M. Cherubini (1994): Evolution of Castanea sativa Mill. in Turkey and Europe. Genetic Research Cambridge 63: 109-111.

Villani, F., A. Sansotta, M. Cherubini, D. Cesaroni and V. SBORDONI (1999): Genetic structure of natural populations of Castanea sativa in Turkey: evidence of hybrid zone. Journal of Evolutionary Biology 12: 233-244.

WeIR, B. S. and C. C. Cockerham (1984): Estimating F-statistics for the analysis of population structure. Evolution 38: 1358-1370.

Herausgeber: Johann Heinrich von Thünen-Institut. Bundesforschungsinstitut für Ländliche Räume, Wald und Fischerei. Schriftleitung: Institut für Forstgenetik, Sieker Landstrasse 2, D-22927 Grosshansdorf Verlag: J. D. Sauerländer's Verlag, Berliner Strasse 46, D-63619 Bad Orb Anzeigenverwaltung: J. D. Sauerländer's Verlag, Bad Orb

Gesamtherstellung: PPPP Norbert Wege e.K., Gladenbach - Printed in Germany. 